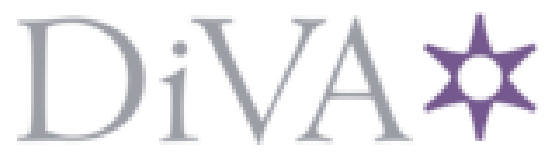

http://www.diva-portal.org

This is the published version of a paper published in International Social Science Journal.

Citation for the original published paper (version of record):

Gillberg, G., Bergman, A. (2013)

Individualisation in working life: work and reflexive patterns among young adults in Sweden.

International Social Science Journal, 64(213/214): 225-236

https://doi.org/10.1111/issj.12051

Access to the published version may require subscription.

N.B. When citing this work, cite the original published paper.

Permanent link to this version:

http://urn.kb.se/resolve?urn=urn:nbn:se:kau:diva-35829 


\title{
Individualisation in working life: work and reflexive patterns among young adults in Sweden
}

\author{
Gunnar Gillberg and Ann Bergman
}

\section{Individualisation and the requirement for self-realisation}

The concept of self-realisation previously had the character of a liberating goal of human endeavour. Today, self-realisation is intertwined with the demands of economic growth (Honneth 2004). In neoliberal ideological discourse, the topic appears together with a stress on the importance of the creative class for economic development (Florida 2012). In the Swedish debate on the manner in which economic advantages are preserved, creativity, entrepreneurship, and innovation have become keywords. At the educational policy level, the discussion has focused on the measures required to stimulate the creative and entrepreneurial potential of children and adolescents. The Swedish National Agency for Education (2011, np) presented the problem as follows:

A flexible labour market imposes new demands on those who come into work today. The educational system needs to adapt in order to respond to changes in society. Entrepreneurship in school is an educational approach in the classroom as much as it is a knowledge of self-employment. It is about identifying and developing students' innate curiosity, initiative and selfconfidence from the very early ages.

The development of entrepreneurial thinking is closely connected to personal attributes, such as curiosity, initiative, and self-confidence. The discussion reflects the realities that await young adults when they step into the labour market. The discussion also clarifies the requirements that society has for young adults. The emphasis on entrepreneurship and innovation may be viewed as part of what the sociologist Nikolai Genov (2012) has described as "spreading instrumental activism", in other words, the belief that the market mechanism acts as a director to solve societal and social problems. The global division of labour and the upgrading of rationality in organisations have led to new demands on the workforce. These new demands are directed at individual responsibility and the ability of individuals to make themselves employable (Ross 2009).

The autonomy and creativity of young adults may be considered necessary and may, in turn, be linked to their capacity for reflexivity. That is, this development fosters expectations about an individual's reflexive ability and cognitive capacity. Being able to understand and deal with a changing and complex world has become imperative (Archer 2012). These new requirements correspond to the changing structure of the Swedish labour market. In Sweden, the number of jobs in the industrial sector has declined dramatically and, as a whole, the labour market has become deregulated (e.g., Sandberg and Movitz 2013b). New demands on 
employees' ability to organise and independently carry out their work have also emerged. Approximately 47 per cent of the jobs now available on the Swedish labour market can be described as low regulated or unregulated in the sense that employees are expected to organise and plan their work more or less independently (Allvin et al. 2013). Further, that young people have difficulty finding employment is obvious and, if they do, they are overrepresented in non-permanent contracts (Tåhlin 2014). Thus, the comprehensive patterns of individualisation in working life should primarily be understood as:

... deregulation aimed to making work more flexible. This kind of deregulation means that rules and norms that have traditionally defined and directed work, in various manners and to varying degrees, are now being soften up or simply abolished. (Allvin et al. 2013, p.218)

The employee must construct his or her own organisational frameworks and management becomes increasingly indirect. Temporary contracts, projects and temporary employment agencies, among others, have made part of the workforce replaceable and have created conditions for numerical flexibility in companies and organisations (Allvin et al. 2011; Standings 2011). Higher education has become increasingly important as a resource because the opportunities in the labour market are still strongly connected to class (Tåhlin 2014). The increasing individualisation of work-related biographies is already recognised as an engine of social and economic development.

However, this development raises profound questions about the consequences of individualisation. In this paper, we focus on these consequences for a specific group, namely young adults, in relation to changing labour market demands. Our contribution to the field is to show that individualisation and individuals' reflexive capacities and abilities to manage these new demands need to be understood as conditioned by their social backgrounds. Therefore, individualisation is not viewed as an explanation in itself but as a consequence of the various social domains within which the reflexive individual lives his or her life.

The structure of the article is as follows. First, the theoretical sections describe the analytical frame. Second, the method and materials are described. Third, the results are presented. Finally, the conclusion is outlined.

\section{Structural conditioning and reflexivity}

As previously pointed out, our theoretical and analytical approach is firmly anchored in the concepts of structural conditioning and reflexivity. Thus, we argue that opportunities need to be understood in light of structural conditioning given the interaction between the process of individualisation in working life and young people's conceptions. However, structural conditioning cannot be discussed without taking into account individual resources and reflexivity.

To understand structural conditioning, a useful theoretical contribution is Layder's theory of social domains (Layder 2004, 2006) because it offers a way to clarify different aspects of social reality when considered in terms of structural conditions. Layder identified four basic domains that condition social life. These domains can be understood as arenas (or levels of social reality) in which structural conditions are produced. The psychobiographical domain comprises the individual's developmental history, which forms his/her psychic structure and contains the emotional experiences that influence our lives from early childhood to the present. The psychobiographical domain comprises the structural conditions of personal identity and the ability of individuals to manage feelings related to the need for security. The second domain is that of situated activities, which concerns the conditions that arise in relation to what one does in daily life and the informal interactions between individuals. Third, Layder uses social settings to comprise the more formal side of situated activities. Many relationships and meetings arise in structured and prearranged surroundings, including the company for which an individual works, and schools, sports clubs, and other types of organisations within which people act and meet. They form structures that exist independent of the individual. Finally, contextual resources are generated at the overall level and span the other three domains. Contextual resources contain both material and symbolic resources and comprise the general social terms that contribute to the formation of social identities. If the individual understands that the resources generated within the framework of social domains are internalised, they can be translated into Bourdieu's concept of an individual's habitus (Bourdieu 1977, 1984). 
The theoretical base for the concept of reflexivity is from the work of Margaret S. Archer (2010, 2012, 2013). Archer argued that today's modern and globalised society is characterised by a reflexive imperative; in other words, the individual is forced to respond reflexively to the world and the prevailing conditions. Intergenerational and intercultural socialisation is still an important factor, although its character has changed in the direction of the transfer of internalised resources in terms of self-esteem, confidence, and action competence. In turn, this transfer affects individuals' reflexive attitude and "modus vivendi". This pressure on the individual becomes particularly visible in young adults who are making the leap into employment and adult life. The concept of reflexivity is connected to the concept of internal conversation as the arena in which the individual's reflexive and intentional sides are forced to deal with the possibilities and constraints of his or her surroundings. Thus, the internal conversation links structure and agency. Through this conversation, the individual reproduces and chooses to transform the self and the surroundings by taking into account his or her concerns and resources. Archer (2000, p.318) writes:

The "inner conversation" is how our personal emergent powers are exercised on and in the world - natural, practical, and social - which is our triune environment. This "interior dialogue" is not just a window upon the world, rather it is what determines our being-in-the-world, though not in the times and the circumstances of our choosing. Fundamentally, the "inner conversation" is constitutive of our concrete singularity. However, it is also and necessarily a conversation about reality.

Thus, by combining Layder's theory of social domains, which provides a framework for understanding how individual and collective resources are generated at different levels of social reality, with Archer's theory of reflexivity and internal conversation, we attempt to understand the nature of the interaction involved in the complex encounter between structural conditions and agency.

To take into account both structural conditioning and reflexivity, we use an analytical figure to understand the experiences and strategies of young adults. Figure 1 provides a sketch of how the changed demands on individuals filter through different social domains and give rise to different reflexive and strategic approaches among young adults. In the first domain, the overall political and social context influences organisations, collectives, and individuals. Second, the social domains condition our lives and generate resources in the form of self-confidence, social networks, knowledge, communities, and economic and symbolic capital. The third domain symbolises individuals' dealings with the conflict between socially conditioned resources and society's needs, demands, and expectations. At the individual level, internal conversations arise regarding possibilities and constraints. The individual mobilises resources and attempts to form strategic decisions that are also emotionally based.

\section{Materials and methods}

Questions related to the new demands in the labour market and their link to self-realisation are further discussed by referring to a series of biographically oriented interviews with young adults in Sweden aged 21-29 years that were conducted during 20072008 by one of the authors. Twenty-two young adults participated in the study, most of whom were interviewed on several occasions. The study was funded by the Department of Work Science at the University of Gothenburg and was part of the doctoral dissertation of one of the authors (Gillberg 2010). Half of the interviewees were in project-oriented entrepreneurship training, in which participants sought to develop their own project ideas and start companies. The interviewees are examples of what the National Agency for Education in Sweden seeks to achieve through its new focus on entrepreneurship. That is, the interviewees embody a fusion of curiosity, initiative, entrepreneurial thinking, and community development. Henceforth, the group is referred to as 'Entrepreneurs'. The second group of young adults discussed in this article were, at the time of the interview, working on the Volvo Cars production line in Gothenburg and represent a group of young adults who have chosen traditional paid work in the industry sector. This group of blue-collar workers is referred to in this article as 'Workers'.

At the time of the interviews, every person in the group of Entrepreneurs had started some form of business or project on his or her own. Many interviewees were already working as project managers. The majority came from a middle-class background, and their parents were mostly very well educated, self-employed, and had experience working abroad. At the time of the interviews, many individuals in the Workers group were 


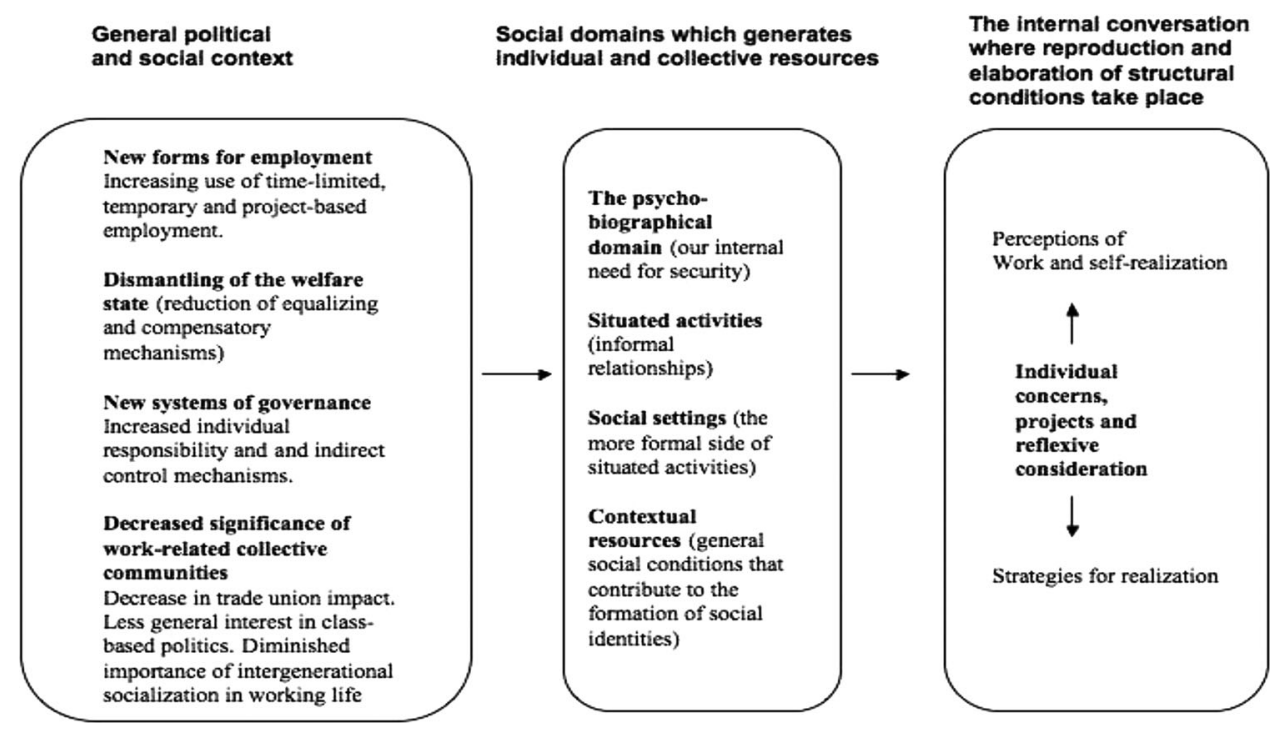

Figure I. Contextual conditions, social domains, and individual consequences Source: Gillberg $(2010,2011)$.

under threat of redundancy. The company (Volvo) employing this group of participants was in a critical situation and concerns regarding the future were apparent throughout the interviews. The parents of most interviewees in this group lacked higher education and worked in the industrial and service sectors. In several cases, the parents worked for the same firm as their offspring. Some of the interviewees were brought into the company by their parents, whereas others found their employment through recruiting firms.

At the time of the interviews, the interviewees were between 21 and 29 years of age. During this period of life, most of them had to make a series of choices related to their different concerns and life projects. Such choices always involve considerations of an intensively reflexive nature. At the time of the interviews, the interviewees were at the intersection of the dream of a good life and the attempt to realise this dream. The interviews were biographically oriented and included interviewees' social and educational background, family situation, and living conditions as key elements. However, the focus of the interviews was the role and significance of work in the lives of the subjects.

Excerpts from some of the interviews are presented later in the article. Key themes are highlighted to illustrate the differentiation in the perception of concerns, opportunities, and constraints between the two groups. The quotes presented are drawn from a deliberate selection of interviews. The selection is made in light of the overall analysis of all of the interviews, and the selected quotations underline the main points of the analysis. To understand how the interaction between the process of individualisation and different social conditions may contribute to different reflexive patterns among young adults, the interviews were analysed using the theoretical points made by Layder $(2004,2006)$ and Archer $(2007,2012)$. The generalisations made from the data are of an analytical nature, and we do not claim to make empirical generalisations because the material does not allow for that.

\section{Young adults' thoughts and experiences on working life}

Although the analytical themes show a global trend in the changed conditions that influence a young adult's aspirations and choices in an individualistic manner, the trend is not equally manifested in the two groups of interest. The first theme is the pressure on the individual to be in control of his or her own life and shape his or her own future. Although the pressure is internalised and expressed by both the entrepreneurs and the workers, they deal differently with such pressure. The second 
common - yet to some extent differently expressed - theme is a matter of self-realisation. The third theme highlighted is about expressed feelings of uncertainty in relation to the future and how the same source of their concern - an uncertain future - gives rise to dissimilar feelings in the groups. Even if we use these themes to identify important areas that trigger an internal conversation, the themes are interrelated, as shown by the presentation of the interviews.

\section{Control}

The entrepreneurs described their working life in transition as a matter that must be controlled. This control implied being forced to be co-creators of societal development. However, some of the interviewees showed a need for resistance and expressed a desire to go their own way and create their own future relatively independently from the demands of society. The tension between the dream of a successful career and the refusal to live up to external demands was present in several of the interviewees.

There are so many choices... and being aware of this makes you feel like a bird in a cage. However, as soon as it's been out and flown it learns what's out there. (Stina, 21 years old)

For the entrepreneurs, the number of choices available seemed enormous and liberating and, simultaneously, a burden. Thus, freedom of choice was a central issue that created the fear of making the wrong choice. The desire to be in control and autonomous and, thereby, to be able to determine one's own work situation was bound to the fear of stagnating or being limited by others. Daniel described this concept in the following manner:

It should be fun... It should be creative... It should be somewhat free... It should be changeable... I shouldn't need to have the same routine for five years... or even for two years. Somehow... I shouldn't feel tied down or stuck either... limited in any way... (Daniel, 25 years old)

For the interviewees in this group, the ability to control their own accomplishments implied creating working conditions, tasks, and companies built around their own interests. This vision was not based on the naive faith in one's own projects. Rather, their desire to create was built on the notion that something in which one passionately and enthusiastically believes can bring new value to the world. The entrepreneurs were concerned about having the resources to realise the dream of having a passionate relationship to their work tasks. In the next step, they were concerned about their ability to thrive on this dream and, thereby, contribute to the development of society. The entrepreneurs were aware of and reflected considerably on the need for money to achieve their personal goals. Some of them pointed out the necessity to, in part, "sell themselves" initially for the sake of future freedom and autonomy. Others spoke of the possibility of obtaining stable part-time employment and devoting the rest of their time to their projects.

Among the workers, to be in control was strongly connected to the desire to be secure. The tension between "what one has and what one can have" was of central importance in the interviews with the workers. In some cases, this tension concerned the experience of lacking or losing control over one's personal life. The workers commonly described having ended up on the shop floor because such work was available to them. In some cases, relatives already worked there, thus providing assistance and someone on which to rely. Johnny described this situation in the following manner:

My dad worked here... and got me in seven years ago and the pay was good... He's worked here for more than 30 years. (Johnny, 25 years old)

In some cases, the work was part of a plan with the view to earn as much as possible as one sought the "dream" education or job. However, among the workers, a tangible element of concern existed over the choices to be made to ensure a secure income for the future. Considering that education might imply less income and require a change of residence frequently counted against pursuing further education. Still, exceptions exist. Josefin provided an example of a life strategy that entails a clear vision of how she saw her future development to be in control of her own life. She had strong support from her parents in this matter:

I have thought, probably since high school, that I would like to do something different for a year or two and then continue studying. I don't know... but it's always been taken for granted that I would study. Mum studied to become a preschool teacher fairly late... I don't know if that has anything to do with it... (Josefin, 24 years old)

David is an example from the opposite side of the spectrum. He expressed a vague vision of what he wants to do and lacks a developed strategy for achieving his dreams: 
I reason in this way. I will work here until I can buy a flat and pay it off ... and then begin to study and do something entirely different... I believe I'd like to be a real estate broker... I don't know... (David, 23 years old)

David's plans of doing something different concerned an indefinite time in the future. His visions were vague and he discussed his plans without taking them seriously. He feared that time was running out and that it was too late for him to study. In his reflections, he expressed conflict between two basic interests: the need for a stable existence with an apartment and no debts, and the longing for a stimulating and creative job. Similar to several other workers, the problem for David seemed to be that he was uncertain about how to realise his plans. The threshold that the realisation of plans needed to overcome was regarded as being too high. David expressed this issue as follows:

But I have no plans for how I'm going to actualise it... Thoughts pop up now and again... sometimes I start to check things out ... but then I just drop it. (David, 23 years old)

The experience of changing demands in a society in transition was just as present for the workers as for the entrepreneurs. To take control of one's situation requires active effort to steer one's own future. To increase employability and, thereby, freedom, well-configured projects and a well-constructed curriculum vitae (CV) were necessary. Interviewees in both groups were influenced by the notion of the individual being responsible for his or her situation. However, the workers thought and acted differently from the entrepreneurs. The workers believed that family, home, and a steady job symbolised security and stability. For example, David described why he chose not to start a training course:

It is probably friends that stops me ... that I need to drop them and the family if I want to educate myself and maybe move. (David, 23 years old)

In contrast to the entrepreneurs, the workers did not believe that everything was possible and they did not regard success as a given outcome of invested time and resources.

\section{Self-realisation}

Work had a central position in the lives of both groups. For the workers, the concept of "a good job" was similar in many ways to the thoughts of the entrepreneurs. Both groups agreed that a good job should, first and foremost, be stimulating such that "one feels one develops as a person in some way" (Josefin, 24 years old). However, the entrepreneurs made striving for self-realisation a more explicit personal goal. In the following quote, Stina emphasises the necessity of combining personal dreams and work:

I believe that my work should be something that ... reflects my current personality... including my interests and all. So, I want my personality and work to go hand in hand ... (Stina, 21 years old)

Stina's wish was that her personality and her work became compatible or even mutually fulfilling. This preference was reflected in the attitude towards money as a means to greater freedom and increased flexibility. Most important was finding work that one liked, and not just to earn money for its own sake. At the time of the interviews, the possibility of having family and children were secondary to work as an arena for self-realisation, a belief that could, of course, be explained by the interviewees' age and current situation (engaged in education); however, the preference reaches beyond such factors. The entrepreneurs described the problem not in terms of the family project itself but, rather, in terms of how to manage this project without reducing desired flexibility. Their hesitation depended on the likelihood that the family project would intrude on the possibilities for self-fulfilment in working life, a belief most clearly expressed in thoughts concerning balance in life. Thus, children and family were an issue in the distant future for most, and viewed as another project to be realised when one's working life stabilised.

On the one hand, all of the workers noted that work is an important aspect of life that cannot be reduced only to income. On the other hand, they expressed that an interesting and developing job is out of reach for someone who is not willing to invest in education. Further, the workers seemed unsure about the type of job that they preferred, and their self-realisation was being put on hold or was regarded as something that they could achieve outside the sphere of work. Christina expressed this concept in the following manner:

I believe there are many young people ... that don't know what they want to be... that they have temporary work. Because I cannot imagine that there is someone who thinks it's so much fun to build cars. (Christina, 23 years old) 
Thus, the workers perceived the possibility of getting an interesting job as a utopian fantasy. They believed that having a house, a family and children was a more realistic dream and that the possibility of self-realisation resides in this family domain. To successfully and strategically navigate in an insecure world requires resources in the form of selfconfidence, supportive surroundings, and a social context of contributing networks and role models. The solution for many of the workers was to strive for a life similar to that of their parents. However, even this possibility could no longer meet their need for security. The factory, which provided stable and lifelong sustenance for their parents, has shifted to an arena subjected to extensive rationalisation and cutbacks. Thus, the "safe" option of choosing to live their parents' life was not as safe anymore. Arguably, visions of work as self-realisation tend to be connected to class but not solely in the ways traditionally conceived. The fact that the individual's working life is becoming increasingly characterised by discontinuity and uncertainty precludes the possibility of forming collective strategies for social change. The consequence of this phenomenon is that workers lacking in resources and self-confidence are prevented from, and in some cases not interested in, becoming the "curious and innovative entrepreneurs" considered the motors of modern society.

Being able to achieve self-realisation within work was so important to the entrepreneurs that they valued this goal more highly than being loyal to an employer and work that reflected the wrong values. The entrepreneurs considered that getting stuck in a firm, company, or organisation was unbearable. Gabriel described this attitude as follows:

The job is such a large part of one's life that it must be enjoyable. There is no way for me to have a job I am not passionate about. ... To be just a part of the machinery will not change our situation here on earth... and we want to create change. (Gabriel, 28 years old)

Against this background, one could say that some of the young entrepreneurs expressed their resistance against being intertwined with the demands for economic growth and development. In contrast, the workers were inclined to adopt a defensive approach to the structural pressures. The ambivalence they experienced derived from the tension between what one believes one should do and what one feels capable of doing. In this context, speaking about a discrepancy between the possibilities one believes are available and the perceived personal ability to realise these possibilities is justifiable. These examples suggest that the difference in visions regarding work and self-realisation are linked to the resources to which one has access. In various ways, these resources are related to the structural conditions and social circumstances of which individuals are a part.

\section{Uncertainty}

None of the young adults interviewed felt that they could rely on a stable and predictable work situation that guaranteed security for the future. The interviewees in both groups were highly conscious of their precarious and uncertain situation. The jobs that their parents considered lifelong and secure may now disappear at any moment given rationalisation and the influence of the global market. The future, both near and distant, was a constantly recurring theme in the interviews in both groups. The entrepreneurs explicitly considered the future as a field of possibilities in which they could actively form their own life and influence society in a broader sense. Still, concerns existed over not being able to meet all of the demands connected to their creative work and lifestyle. The workers expressed the future as uncertain and that influencing it by themselves was not possible. Although they were aware of the pressure on themselves to be active in the creation of their own personal future, they did not aspire to change the conditions and paths of their own context. Instead, they were occupied by thoughts of whether or not to change themselves and their lifestyles.

In both groups, the interviewees' uncertainty about the future generated a number of concerns. The workers expressed feelings of ambivalence over what to do with their current situation to be able to form their own preferred future. The entrepreneurs expressed feelings of their own inadequacy and sustainability in relation to their own and others' expectations. Their fear of inadequacy was related to their concern over not being good enough and, therefore, not needed in the long run. Concerns also existed over personal health, described in terms of not being able to live up to the expectations and demands of their aspirations. Their worries contributed to performance anxiety, which Jonathan described as follows: 
At times, I have said I am my own worst enemy due to my striving for a level of quality that I must always achieve, and if I haven't quite reached it I think that ... this is not quite good enough... (Jonathan, 27 years old)

Even if the high expectations for their performance came from themselves, some expressed that they also faced expectations and demands from home. However, at the same time, they emphasised the importance of parental encouragement for their own success now and in the future. They described their parents' support for developing freely and following their own desires. Instead, participants' conceptions of society's demands in relation to their own capacity were brought forth. Competition was perceived as difficult, particularly in areas of work that fulfil the important desire of being in control of their own situations. Their freedom was to be achieved through hard work and high self-demands, and a fear of inadequacy arose in connection with these demands. The imminent threat was most commonly described in terms of the inability to psychologically cope with the demands.

Therefore, entrepreneurs' ideals of selffulfilment, as previously described, can be said to correspond to society's proclamation of the importance of the role of the entrepreneur in economic and social development. Even if the entrepreneurs in some cases experienced society's demands as a burden, they also understand it as a resource when attempting to live up to this belief and to related expectations. Thus, the entrepreneurs' internalised values can be understood as enabling resources in a situation that emphasises individual responsibility as a way to handle internal and external demands. The entrepreneurs shared the combined characteristics of having original ideas, a passionate dedication to work, and a sense of social responsibility:

It is the accountable entrepreneur that must bear the weight ... to change the way of seeing things and influence consumption patterns and trends. (Gabriel, 28 years old)

The flip side of the coin appeared in expressions of self-exploitation and manifested in conscious anxiety over mental exhaustion in the future. In response to these anxieties, thoughts of resistance emerged through reflections on alternative ways of living and working to still be in charge of their lives.

Among the workers, concerns about the future were expressed in terms of ambivalence. Many of them described considerable insecurity when faced with the life choices to be made. The explanations offered include a fear of studying and a lack of motivation. The available alternatives were experienced as distant and difficult to actualise, but they still believed that they should do something about the situation. Christina described this phenomenon as follows:

It's probably true that I am very complacent... It's very comfortable to go to work every day and collect your pay... and you're afraid ... well not really afraid, either, since I want to work within the tourist trade and must take the leap... but I haven't done it. The greatest obstacle is if I don't go back to school or do something about it... I'm holding myself back all the time... that I just don't do anything about it. Yes... you get complacent when you work here... (Christina, 23 years old)

All of the workers expressed uncertainty over whether their jobs will remain or will suddenly disappear at the factory, which triggered ambivalence about what to do. This ambivalence expressed in "should I stay or should I go" was further based on feelings of shame for not "moving on" and, at the same time, on considerations about security and estimations for what they believe is realistic for them.

Workers thoughts concerning the factory came through in all of the interviews. One recurring topic was that the work was only temporary and that interviewees sought better alternatives. However, most employees remained working in the factory for longer than they expected. In many cases, they expressed a sense of stagnation that, in turn, generated thoughts of changing their situation. However, leaving the work was also viewed as a risk. Christina described her worries regarding going back to school as rooted in the impression that studying is difficult, time-consuming, and expensive:

When I started I said one year... but now four years have passed, so... I believe you can get stuck if nothing is done quickly about the situation. It is those that have been here 30-40 years; they complain but do nothing about it. If I'd been thinking of what's best for me, I should have looked for something new as soon as possible or begun studying something I enjoy.... to have something to look forward to during the day ... but I don't do it ... Don't know why ... no motivation to study. (Christina, 23 years old)

When reflecting on work and the future, the workers expressed ambivalence towards the possibilities at hand. This ambivalence appeared rooted in the desire to control the situation and for security, and concern over the risks involved in "breaking the mould". Thus, control was understood as syn- 
onymous with steady work, a steady income, and proximity to friends and family. Many reflected on the increasing demands of society and showed uncertainty regarding their ability to meet these expectations given a perceived lack of personal ability and motivation. Although education and free choice are self-evident priorities among the entrepreneurs, having work and a steady income appeared to be most important to the workers. In other words, the lives and visions of these young adults may be said to have been influenced by classrelated strategies and choices.

These interview excerpts may be understood as expressions of internal conversations that take the form of diverse considerations, viewpoints, and visions of how work and life are addressed and understood. The questions of being in control of one's life, of how to achieve self-realisation, and of how to deal with uncertainty are common areas that trigger concerns; through these questions, internal conversations and reflexions emerge. The interviews also depicted young adults' way of understanding and handling their situations as influenced by the resources at their disposal. Thus, a relevant question to consider is: How can the influence from different "social domains" in Figure 1 be comprehended in relation to the interviewees' visions and reflexive considerations? In the remaining part of this article, we dwell on what we believe is its main contribution, in other words, that individualisation and individuals' reflexive capacities and abilities to manage these new demands need to be understood as conditioned by their social backgrounds.

\section{Structural conditions and individual resources}

Today, one sees tendencies for lifelong learning, entrepreneurship, and creativity to transform from possibilities into demands. Honneth (2004) described the process through which the concept of self-realisation has changed from being a utopian goal to being a societal demand. This study shows that self-realisation is already a pronounced part of the characterisations of young adults' views of themselves and of working life. Self-realisation and work are now intertwined with the demands of increased competitiveness, economic growth, and rapid development. In addition to self-realisation, the notion of being in control of one's life and being able to handle uncertainty also generates new demands on individuals irrespective of class. These demands force individuals to respond reflexively and strategically to an ever-increasing number of complex questions. The consequences vary depending on the personal and social resources that the individual is able to mobilise, on the communities to which one belongs, and on the emotional and cognitive characteristics that one has integrated into one's own personality. Contextual resources (for example, the union and labour movements), which previously functioned as the basis for social identity and collective strength for many of the labour market's more vulnerable groups, have lost power (e.g., Bruhn et al. 2013). Today, the individual stands alone and can only trust the support of his or her social surroundings and the personal resources acquired when growing up. Beck (1992) and Beck and Beck-Gernsheim (2005) described this situation as an expression of an ever-increasingly individualised class society (Devine et al. 2005; Howard 2007).

To a significant extent, contextual resources have their origin in collective agency on the basis of stable and common work-life experiences. However, during transitions and discontinuity, conditions change in a way that obstructs the formation of common social identities. The global division of work has transformed the very foundations of the power relations of the Swedish labour market (Allvin et al. 2013; Sandberg and Movitz 2013a, 2013b). One consequence is that the stable identification patterns provided by the contextual domain lose their significance for the working class. Therefore, the concerns that the workers expressed over their situation and possibilities at hand can be understood as a product of this discontinuity. Their ambivalence over their future work life is partly a consequence of no one in their social surroundings being able to provide guidance and alternatives.

Resources linked to the individual's psychobiography are considered to become increasingly important in explaining his or her control of surroundings characterised by discontinuity (Archer 2012). A connection exists between the individual's psychobiography and his or her ability to develop successful strategies for succeeding in the labour market. However, this connection does not necessarily indicate that specific social conditions produce specific types of psychobiography. However, the background of the interviews makes it apparent that resource-weak social surroundings 
create poorer conditions for the development of an independent action repertoire and, thus, for the ability to handle change. The conclusion may be drawn that the interviewees perceive a complex and transitional world that must be handled in new and, in many cases, unknown ways. Further, characteristics such as flexibility and capability are largely conditional on the interviewee's background and social surroundings (Brannen and Nilsen 2005; Furlong and Cartmel 2007; Sayer 2005).

The general conclusion is that the rapid pace of change caused by global competition and work distribution creates a contextual discontinuity (Archer 2012). This change reinforces polarisation in both the labour market and society, and complicates the maintenance of collective communities that rest on the foundation of shared experiences of working life (Allvin et al. 2011). The individual is left alone with his or her own ability to construct arenas for socialisation, which in turn increases the demands placed on an individual's psychological and emotional resources.

\section{Individualisation of working life: challenges to young adults}

As in many other western countries, the transition period between youth and adult has been prolonged in Sweden, and young people's establishment in the labour market is characterised by uncertainty, non-linearity, and questionable confidence in the process (Furlong and Cartmel 2007). This study supports these findings because growing up in contemporary - Swedish - society means growing up in a society impregnated by subjectively experienced uncertainty, irrespective if whether one is resourcestrong or resource-weak. Therefore, late modernity becomes paradoxical because, arguably, the overall contextual conditions for social life are marked by increased discontinuity and rapid change. At the same time, structural factors are relatively stable and enable or restrict young adults from realising their dream of a good life.

As has been argued, changes in contextual conditions force individuals to respond reflexively to themselves and to the new demands regardless of their backgrounds and resources. An unambiguous link exists between the reflexive patterns of young people and the resources generated within the var- ious social domains. To understand the effect and consequences of the individualisation of the working lives of young people, the relationships between their psychobiographies, the situated activities, and the social settings in which they live need to be studied. Such a study appears to be particularly important at a time when self-esteem and the individual's ability to navigate between choices and options are becoming increasingly decisive selection mechanisms. Further, the outcomes of studies in the field of individualisation and individual reflexivity need to take into account overall structural changes in society.

Contextual discontinuity has changed the prerequisites for the establishment of stable collective communities, particularly those associated with work and social identity. One consequence of these "individualised" conditions is that resources generated at other structural levels have become increasingly important in the encounter between the individual and his or her environment. Resources generated within the family context and the local social environment become important selective mechanisms that give rise to different reflexive patterns. On the basis of the interviews, three common areas have been distinguished that trigger the entrepreneurs' and the workers' reflexive capabilities and that allow for identification of different reflexive patterns that in some cases are enabling and in others are not.

The first area is primarily related to the aspiration of being in control of one's own life, and in which the resource-poor group considered security and the resource-strong sought autonomy and freedom. The second area takes the form of a desire to manage increased individualisation through self-realisation, in which the workers had a more cautious approach and saw the minimal possibilities of self-realisation in work. In contrast, the entrepreneurs took their self-realisation for granted as both an end and a means in their lives. The third area was the concern over an uncertain and unpredictable future in relation to work. The entrepreneurs' reflexive patterns can be summarised as those of an active agent and co-creator of the future, whereas the workers appeared ambivalent with respect to choices and opportunities. These ambivalent reflexive patterns emanated from settings and activities that lacked the ability to generate these personal and collective properties. 
Hence, individualisation and its consequences emerge from the tensions between the "reflexive imperative" (Archer 2012) and the various social domains (Layder 2006) within which individuals live their lives. All young adults in the study make reflexive choices but do not have the same possibilities to realise them. The social settings and the situated activities that produce resources in the form of self-confidence and favourable social networking serve as factors that strengthen both autonomous reflexive patterns and resistance to the existing order. Thus, the conclusions that emerge from the empirical material are as follows. Changing contextual conditions compel individuals to relate reflexively to themselves and to their environment. Reflexive patterns are always established in relation to the resources that an individual has in his or her "baggage". These resources develop through the framework of the various social domains within which the individual lives his or her life. Consequently, individualisation is an effect of changing contextual conditions and not an explanation per se.

The concept that opened this article concerned the desire for, and the possibility of, developing a new "creative class" that will assist in creating jobs and growth. This concept has become part of the dreams and beliefs of work that characterise the lives of many young adults. For some, these dreams and beliefs translate into opportunities and an increased risk of self-exploitation as the responsibilities and requirements become internalised and intertwined with the notion of self-realisation. For others, these dreams and beliefs translate into concern and ambivalence based on the unequal distribution of resources in a broad sense. This aspect reveals the different conditions in which young adults live their lives. The ability to reflexively address uncertainty and change is not a given. Even in cases in which restoring or maintaining a situation that resembles one's parents' way of life is desirable, one must mobilise the reflexive capacities because the possibility to take over one's parents' way of life is becoming increasingly difficult as working life is restructured (Archer 2012).

The individualisation of risks is equally applicable to the worker and the entrepreneur because all individuals must bear an increasing responsibility for their own well-being, success, and security.
It is appropriate to state that a new relationship has emerged between the individual and society. The individual's freedoms and responsibilities have increased at the expense of security and stability. These new individualised conditions increase the autonomy and the opportunities available to the entrepreneur (with increased risk of failure, stress, and exhaustion). The workers find their access to these new vistas restricted by a lack of personal resources. The dream of self-realisation is just as applicable to this group as to the entrepreneurs; however, self-esteem, role models, collective compensatory and mobilising factors, as well as an enabling social environment, are lacking. To understand the patterns of unequal life chances, class must be perceived as an expression of individuals' access to external and internal resources.

Axel Honneth (2004) stressed the point that Western capitalist development since the 1980s has resulted in a change in the perception of selfrealisation. From having been a life goal worth pursuing, the notion of self-realisation has transformed into an ideology and a productive force adapted to an increasingly deregulated and individualised working life. At the same time, neoliberal discourse questions the roles of class and social background; accordingly, young people's opportunities and life chances are described as expressions of free individual choice. Self-realisation has become an imperative directed at the individual. The associated demands are conjoined with increased individualisation of responsibility and being in charge of one's own life and choices. This change involves a fundamental restructuring of working life that should be viewed primarily as a response to an increase in global competition. Its effects are best summarised in terms of increased flexibility and transfer of responsibility to the individual. This article attempted to show the implications of these changes for young adults in Sweden and emphasises that the individualisation of responsibility in terms of control, the demand for self-realisation, and dealing with uncertainty generates different consequences for different groups in society. Therefore, reason exists to strongly challenge the notion that class has played out its role as an analytical tool in modern society. In contrast, the interviews show that class is as important as ever, but in a new way. 


\section{References}

Allvin, M., Meller, C., Movitz, F. and Aronsson, G. 2013. The diffusion of flexibility: estimating the incidence of low-regulated working conditions. Nordic journal of working life studies, 3 (3), 99-116.

Allvin, M., Aronsson, G., Hagström, T., Johansson, G. And LundBerG, U., 2011. Work without boundaries. Psychological perspectives on the new working life. Oxford: Wiley-Blackwell.

Archer, M.S., 2000. Being human: the problem of agency. Cambridge: Cambridge University Press.

ArCher, M.S., 2007. Making our way through the world. Human reflexivity and social mobility. Cambridge: Cambridge University Press.

ArCHER, M.S., 2010. Reflexivity's transformations: the demise of routine action and its consequences for civil society. Conflict, citizenship and civil society. S. 31-50.

ARCHER, M.S., 2012. The reflexive imperative in late modernity. Cambridge: Cambridge University Press.

ArCher, M.S., 2013. Social morphogenesis. Dordrecht: Springer.

BЕСК, U., 1992. Risk society: towards a new modernity. London: Sage Publications.

Beck, U. And Beck-Gernsheim, E., 2005. Individualization. London: Sage Publications.

Bourdieu, P., 1977. Outline of a theory of practice. Cambridge: Cambridge University Press.

Bourdieu, P., 1984. Distinctions: a social critique of the judgement of taste. Cambridge, MA: Harvard University Press.

Brannen, J. ANd Nilsen, A., 2005. Individualisation, choice and structure: a discussion of current trends in sociological analysis. The sociological review, 53 (3), 412-428.

Bruhn, A., KJellberg, A. AND SANDBERG, A., 2013. A new world of work challenging Swedish unions? In: A. Sanberg, ed. Nordic lights: work, management and welfare in Scandinavia. Stockholm: SNS Förlag, 126-186.

Devine, F., 2005. Rethinking class: culture, identities and lifestyles. Basingstoke: Palgrave Macmillan.

FLORIDA, R., 2012. The rise of the creative class. New York: Basic Books.

Furlong, A. and Cartmel, F., 2007.

Young people and social changes: new perspectives. Buckingham: Open University Press.

Genov, N., ed., 2012. Global trends and regional development. London: Routledge.

Gillberg, G., 2010.

Individualiseringens villkor. Unga vuxnas föreställningar om arbete och självförverkligande [The conditions of individualization: conceptions of work and self-realization among young adults]. Göteborg: Gothenburg University [In Swedish with an English summary].

Gillberg, G., 2011. Arbete och självförverkligande: Unga vuxna i spänningsfältet mellan passion och exploatering [Work and self-realization. Young adults in the tension between passion and exploitation]. In: T. Bergqvist, G Gillberg and L. Ivarsson, eds [Work: passion and exploitation], Växjö. [Work Life in Transition] No. 03/2011, 86-105 [In Swedish].

Honneth A., 2004. Organized self-realization: some paradoxes of individualization. European journal of social theory, 7 (4), 463-478.
Howard, C., ed., 2007. Contested individualisation: debates about contemporary person hood. Hampshire: Palgrave Macmillan.

LAYDER, D., 2004. Emotions and social life: the lost heart of society. London: Sage Publications.

LAYDER, D., 2006. Understanding social theory. Sage: London.

Ross, A., 2009. Nice work if you can get it: life and labor in precarious times. New York: New York University Press.

SANDBERG, A. AND Movitz, F., 2013a. How bright are the Nordic lights? In: $\AA$. Sanberg, ed. Nordic lights: work, management and welfare in Scandinavia. Stockholm: SNS Förlag, 13-28.

SANDBERG, Å. And Movitz, F., 2013b. Contested models: productive welfare and solidaristic individualism? In: $\AA$. Sanberg, ed. Nordic lights: work, management and welfare in Scandinavia. Stockholm: SNS Förlag, 31-90.

SAYER, A., 2005. The moral significance of class. Cambridge: Cambridge University Press.

Standings, G., 2011. The precariat: the new dangerous class. London: Bloomsbury.

Swedish National Agency for EDUCATION, 2011. Skolverket. Stockholm. Available at: http://www.skolverket.se/sb/d/2810 2010-09-30 [accessed 12 March 2013].

TÅHLIN, M., 2014. Arbetslivets gränser. Sysselsättning, matchning och barriärer. In: M. Evertsson and C. Magnusson, eds. Ojämlikhetens dimensioner. Uppväxtvillkor, arbete och hälsa i Sverige. Stockholm: Liber, 236-262 [In Swedish]. 